\title{
Nitrogen transformations from nitrogen fertilizers in soils of central and eastern Europe in changing climatic conditions
}

\author{
Barbara Gworek ${ }^{1}$, Jan Łabętowicz², Marta Kijeńska ${ }^{1 *}$, Lidia Tokarz ${ }^{1}$, Andrzej Barański ${ }^{1}$ \\ ${ }^{1}$ Institute of Environmental Protection - National Research Institute, Krucza Str. 5/11d, 00-548 Warsaw, Poland \\ ${ }^{2}$ Warsaw University of Life Sciences - SGGW, Institute of Agriculture, Nowoursynowska Str. 159, building no. 37, 02-776 Warszawa, Poland \\ * Dr. M. Kijeńska, marta.kijenska@ios.edu.pl, ORCID iD: https://orcid.org/0000-0002-5191-4318
}

\begin{abstract}
Received: 16.06 .2020

Accepted: 14.01.2021

Associated editor: B. Glina

\section{Keywords}

Climate change

Nitrogen

Fertilizers

Agriculture

Soil

Nitrous oxide

Agriculture contributes to global warming mainly through the emission of methane and nitrous oxide. Nitrous oxide is particularly important, as it accounts for a significant share of total nitrogen emissions from arable land It is produced as a result of anaerobic microbiological changes of nitrogen introduced into the soil along with mineral fertilizers. Changes in weather patterns in response to climate change may significantly affect the efficiency of fertilizer nitrogen in agriculture, and, consequently, entail undesirable environmental effects. This issue is of particular importance in view of the dominant role that this fertilizer element plays in agriculture, and, on the other hand, due to the global environmental risk within the "nitrogen cycle". The analysis, carried out in this paper indicates, that transformations of nitrogen compounds in the soil, caused predominantly by the climate condition, result in nitrogen release from the agricultural production area. The dispersion in the form of molecular nitrogen $\left(\mathrm{N}_{2}\right)$ is mainly the result of denitrification processes. By this way over $50 \%$ of nitrogen lost from agriculture is dissipated from the agricultural land. From the agricultural point of view, denitrification is a process that limits the resources of available nitrogen, but from the environmental viewpoint, this process should be considered as a natural mechanism of environmental self-purification and water protection. Although it constitutes only about $25 \%$ of the total loss of this element the dilution of nitrogen from agricultural areas by leaching, is considered to be the most cumbersome for the water environment.
\end{abstract}

\section{Introduction}

The assessment of impact of weather conditions on the transformation of nitrogen compounds introduced as organic and mineral fertilizers has long been a subject of research, but changing weather conditions related to global warming imply a reassessment of this impact, especially in the context of environmental effects (Olesen et al., 2011). The aim of the study is to summarise the knowledge on the impact of moderate climate conditions on the nitrogen transformations in soil.

Over the last several decades the term 'climate change' has assumed a new meaning in the context of global warming and temperature rise on the Earth surface, while causes of climate change have been intensively studied on the global scale. The present state of knowledge on the causes of climate change has been specified by consecutive reports of the Intergovernmental Panel on Climate Change (IPCC). These reports as well as other accounts, such as that of the American National Academy of Sciences (NAS), as well as the report published by the G8 Group, state that most of temperature changes over the last 50 years shall be attributed to human activities. The temperature rise, observed in the years 1906-2005 near the Earth surface, was $+0.74 \pm 0.18^{\circ} \mathrm{C}$ (IPCC 2007), and the decade 1999-2008 being the warmest decade for the past hundred years (Wang et al., 2010). IPCC suggested that global mean air temperature may rise by up to $+6^{\circ} \mathrm{C}$ by the end of the $21^{\text {st }}$ century (Oni et al., 2017). The European Union has been undertaking climate protection activities globally since the 90 -ties of the 20th century. The EU has played a key role in establishing the United National Framework Convention on Climate Change and the Kyoto Protocol. The Protocol sets the legally binding goals for the industrialized countries, aiming at the reduction of emission of greenhouse gases (GHG) and as effect in the beginning of $2007 \mathrm{EU}$ has set an ambitious goal - to reduce the emission of GHG by at least $20 \%$ by 2020 .

Agriculture is also responsible for emitting GHG to the atmosphere, albeit at a lower scale than the other sectors. This applies, in particular, to large-scale and industrial agriculture. It is estimated that this share does not exceed $10 \%$ of the emissions produced by the national economy (Sapek et al., 2002). A relatively small share of agriculture in the global GHG emission is due to the fact that agricultural land, covering more than 
half of the EU surface area, is a large coal stock. The $\mathrm{CO}_{2}$ emission from soils is compensated by its absorption by plants, and, as a result, agriculture contributes to reducing its emission. Agriculture contributes to global warming mainly through the emission of methane and nitrous oxide. Particularly significant is the share of nitrous oxide, which accounts for as much as $50 \%$ of the total emission of GHG from agricultural land. The annual global $\mathrm{N}_{2} \mathrm{O}$ emissions from soils are comparable to the $\mathrm{N}_{2} \mathrm{O}$ emissions from fossil fuel combustion (Oertel et al., 2016), and in Poland almost $80 \%$ of the annual $\mathrm{N}_{2} \mathrm{O}$ emissions originate from agriculture, and its main source is the use of agricultural soils (Wiśniewski, 2019). It is produced as an outcome of microbial transformation of nitrogen introduced into the soil with mineral fertilizers. It is expected that, with regard to agriculture, the increasing probability of extreme weather events will result in a significant increase in the risk of failed harvest. Extreme weather events will primarily involve restrictions on the availability of water resources and floods. It is estimated, that yields harvested on more than $80 \%$ of agricultural land in Europe depend on the amount and distribution of precipitation. Water shortage in agriculture poses already a challenge in many parts of Europe, and this state is likely to worsen. Weather scenarios predict, that by 2070 , there will be an increase in water deficient areas in Europe, from the current $19 \%$ to $35 \%$ (Iglesias and Garrote, 2015). It is known, that nitrogen cycle processes in terrestrial ecosystems are highly sensitive to temperature and soil moisture changes (Dirnbőck et al., 2017). Within this context, the relevance is increasing of the effect of climate changes, which result in significant fluctuations in soil moisture and temperature, on the transformation of soil nitrogen, particularly of the nitrogen introduced with natural and mineral fertilizers.

Changes in weather in response to climate change may significantly affect the efficiency of fertilizer nitrogen in agriculture, and, consequently, entail undesirable environmental effects. This issue is of particular importance in view of the dominant role that this fertilizer element plays in agriculture, and, on the other hand, due to the global environmental risk within the nitrogen cycle.

\section{Conditions of nitrogen fertilizer transformation in the soil}

The transformation of nitrogen compounds in the soil environment is influenced by multiple factors related to soil properties including $\mathrm{pH}$ and exchange capacity, its reaction as well as farming practices, which vary greatly, depending on the level of agricultural technology. In this context, studies on the effect of weather conditions on transformations of nitrogen fertilizers are difficult to make an unambiguous estimate, and, in particular, to make a quantitative evaluation.

\subsection{Conditions related to the content of organic carbon.}

As it is known, nitrogen is present in the soil surface layer mainly in the form of organic compounds. They represent more than $90 \%$ of the total soil nitrogen (Stevenson, 1982). Polish soils contain small amounts of nitrogen. The content of the total nitrogen in soils ranges from 0.02 to $0.35 \%$. Chernozems, black earths and peat soils are more rich in nitrogen. However, most of the soils in Poland are sandy soils containing no more than $0.1 \% \mathrm{~N}$. The transformation of soil nitrogen is quantitatively associated with the transformation of organic carbon. It depends on the same factors, which determine the processes of decomposition and synthesis of soil organic compounds, including soil humus. The content of soil organic matter and the associated nitrogen content, which is usually about $5 \%$ of its amount, is a function of contrasting processes of mineralization and humification of organic matter. These processes, as microbiological processes, are strongly affected by temperature and humidity of the soil environment. Organic carbon is the basic energy and building material for soil microorganisms (Bouwman et al., 2013, Laegreid et al., 1999)

The direction of mineralization processes is determined by the ratio of carbon to nitrogen in the organic fertilizer material. If, in the organic fertilizer material, this ratio is significantly bigger than in the microbial biomass (excessively wide: $\mathrm{C}: \mathrm{N}>40: 1$ ), immobilization processes dominate, whereas when it is narrower $(<20: 1)$, then there prevail mineralization processes.

The significant effect of these transformations, dependent on the $\mathrm{C}: \mathrm{N}$ ratio in the organic fertilizer material consists. In the first case, in the plant's disadvantage due to the decrease in the mineral nitrogen forms in the soil, and, in the second case, in the beneficial to plants rise in the soil mineral nitrogen. This decrease can significantly modify the effect of weather conditions on nitrogen transformation in the soil, as a result of multiple interactions of various intensity. Mineralization and immobilization processes are an essential part of the small nitrogen cycle within the soil-plant system. This circulation is closely related to the so-called large cycle, in which nitrogen present in the atmosphere takes part (Mariano et al. 2016).

\subsection{Conditions associated with agrotechnical treatment}

It should be emphasized that under conditions of cultivated soils, the transformation of nitrogenous organic compounds to mineral forms and their re-conversion to organic forms, depends not only on weather conditions, but also on agrotechnical factors related to cultivation (mechanical or no-till), fertilization technique (on-surface or in-depth application now increasingly in use), and on plant protection treatments (impact on the state of microorganisms), which significantly modify the supply of atmospheric air to the soil environment and the soil microbial activity. This makes it difficult to precisely assess the impact of weather conditions on nitrogen transformations. Separation of the above effect from that of the cultivation technology often encounters methodological problems, what leads to a considerable divergence of results obtained by various researchers.

The experiment which was carried out by Nivelle et al. (2016) in Northern France confirmed that agricultural practices have significant influence on content of $\mathrm{C}$ and $\mathrm{N}$ in soil. Combining no-till with winter cover crops (with a low or a high prevalance of legumes), irrespective of the presence of $\mathrm{N}$ fertiliz- 
ers, resulted in the end of the experiment with increased of the total soil organic C and $\mathrm{N}$ contents above $20 \%$ over the course of 5 years.

\subsection{Conditions associated with the heterogeneity of the soil environment}

The soil environment is a very heterogeneous system. This is, to a large extent, due to its three-phase nature with varying proportions of individual phases and their differentiated spatial layout. This intricate system is additionally complicated by the heterogeneity of the soil solid phase itself, with all its layers and microspaces formed by its lumpy structure. Moreover, soil is an environment, in which various transformations of organic and mineral nitrogen compounds are directly related to the functioning of microorganisms, or to biochemical reactions controlled by enzymes secreted into the soil environment by living cells, or those entering after their death and degradation. This complexity of the soil environment favors the coexistence of a variety of biological processes that require extremely different conditions. As a result, nitrification and denitrification processes commonly occur in parallel (Stein and Klotz, 2016). The first occurs under conditions of good oxygenation, while the other requires anaerobic conditions. The scheme of the nitrogen cycle in the environment was presented in Fig. 1.
3. The effect of weather conditions on transformations of nitrogen supplied to soils as organic fertilizer materials

Organic fertilizer materials introduced into the soil environment are incorporated into the microbial transformation cycle, which develops a specific, weather-dependent balance of mineralization and immobilization processes. The driving force behind these processes is the energy released by the transformation of carbon compounds. The equilibrium formed under these conditions is strongly shifted towards the formation of organic compounds, mainly proteins and humus compounds, what is related to the formation of humus fractions resistant to mineralization. As a result, the mineral nitrogen forms in soils account for only 1 to $5 \%$ of the total soil nitrogen. The equilibrium of the above processes at this level is determined by the relative ratio of carbon and nitrogen contents in the organic material, which is due to the energy needs of soil microorganisms. The main factor responsible for maintaining the above balance is a good oxygenation of the soil environment. Theoretically, such conditions occur at low soil moisture. However, due to the microbiological character of the transformation of organic compounds, the peak mineralization occurs at the humidity optimum for the soil microorganisms. In practice, the differences in the mineral nitrogen content, and thus the differences in the rate of organic com-

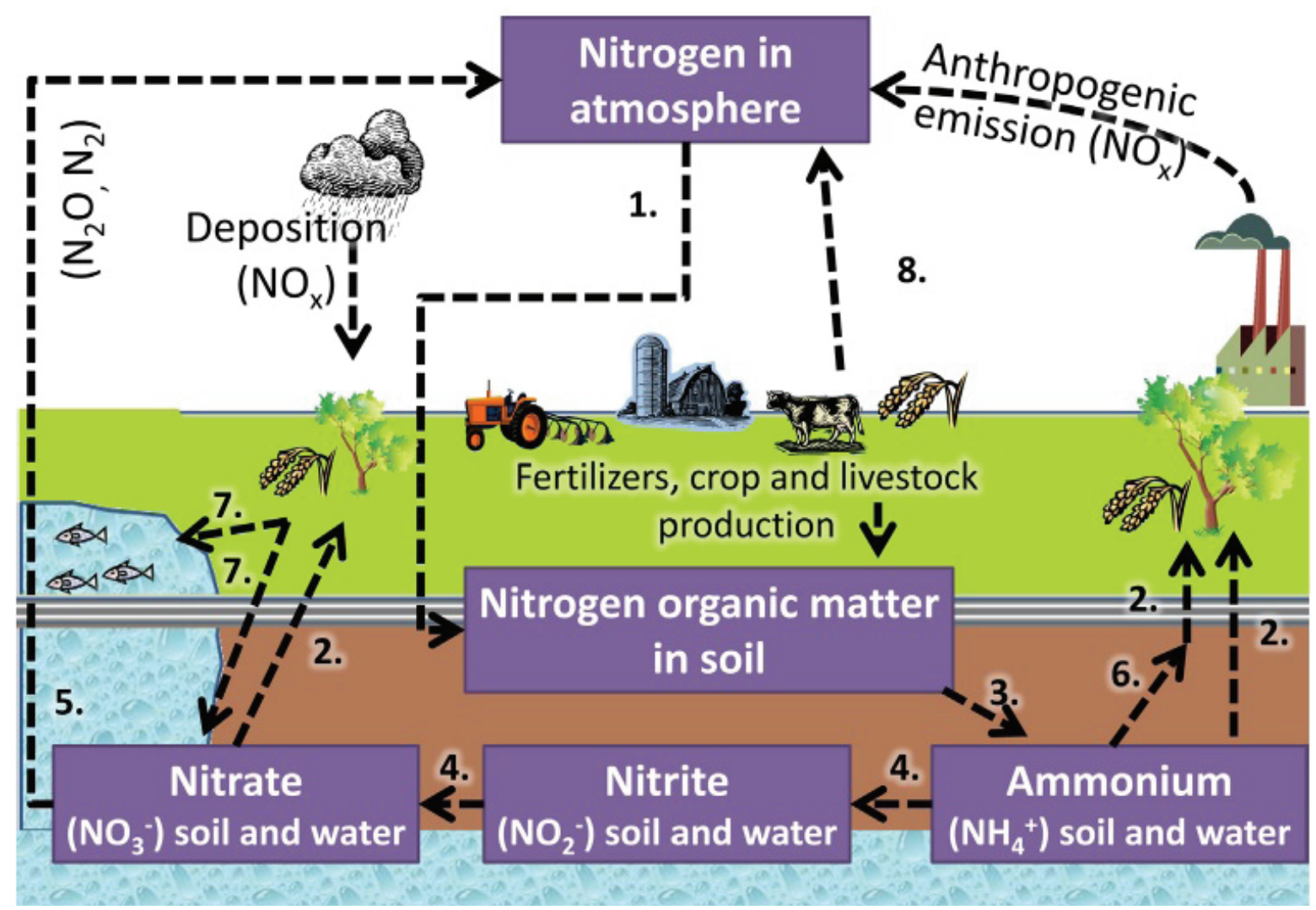

Fig. 1. The nitrogen cycle in the environment (after Bednarek et al., 2014). The nitrogen cycle: (1) uptake of nitrogen by plants from the atmosphere, (2) uptake of ammonium and nitrate by plants from soil and water, (3) ammonification, (4) nitrification, (5) denitrification, (6) nitrate immobilization by soil sorption, (7) nitrate leaching from the soil, (8) release of ammonia $\left(\mathrm{NH}_{3}\right)$, gaseous nitrogen and nitrous oxide to the atmosphere 
pound mineralization, change only slightly in a relatively wide range of soil moisture levels. It is to be expected, that the lack of precipitation for a short time period, during the growing season, will have little impact on mineralization processes of organic fertilizers introduced into the soil. Low temperatures and excess water in the soil environment persisting for an extended period of time create an anaerobic milieu which reduces microbial activity in the soil environment. This limits the rate of mineralization and promotes the long-term accumulation of organic matter, thus contributing to the growth of soil organic nitrogen. This also applies to any fertilizer forms of organic matter entering the soil. Likewise, under conditions of high temperatures and soil drought microbial activity is reduced, what leads to reduction of $\mathrm{N}_{2} \mathrm{O}$ production (Inglett et al., 2005, Zhang et al., 2019).

High temperatures, while ensuring the optimum soil moisture, create conditions conducive to shifting the balance of microbial processes towards the organic matter mineralization, what results in the release of organic nitrogen and the formation of mineral nitrogen forms, such as ammonium forms, which, as a result of further changes, undergo oxidation processes to nitrates. The organic fertilizer material used in such conditions will be a good source of nitrogen for plants. The impact of soil temperature and moisture on the mineralization rate of soil nitrogen was recognized in the 1970s of the last century by Stanford et al. (1973, 1974). They showed that the mineralization of soil nitrogen follows the van Hoff's rule, that the temperature increase by $10^{\circ} \mathrm{C}$ increases the intensity of mineralization twice.

Weather factors are however, an important environmental pollution when applying organic fertilizer. In temperate climates, changes in the dynamics of temperature and humidity during the vegetation period have increasingly been observed. If, after the application of organic fertilization under a spring plant, the weather pattern during the initial vegetation period will be characterized by drought periods, whereas later in that period there will be a change in weather circumstances, consisting in an improvement in soil moisture conditions, undesirable environmental effects may be expected. Under these conditions, the main rate of mineralization will be significantly moved beyond the vegetation period, what will lead to the occurrence of mineral forms of nitrogen that cannot be used by the crop, and will be subject to the risk of leaching or release during autumn and winter and early spring (Erbas and Solakoglu, 2017; Rutting et al., 2018).

Meteorological factors, and, in particular, temperature and precipitation, have a significant effect on the rate of mineralization of soil nitrogen, which is one of the major causes of a high variability of mineral nitrogen forms in the soil during vegetation. This is an important obstacle when using chemical methods for determining the content of plant available nitrogen in the soil (Haohao et al. 2017; Luce et al., 2011). Contemporary systems of fertilization diagnoses take into account the effect of weather conditions on the mineral nitrogen content in soils. For diagnostic purposes, the content of mineral nitrogen in the soil is usually determined early in the spring, before the vegetation starts, when the soil microbial activity is still at its minimum, due to the low soil temperature (Arbacaukas et al., 2018; Villar et al., 2019).

The transformation of organic nitrogen compounds in the soil environment leads, ultimately, to the formation of ammonium, which is the basic form of nitrogen that can be taken up by plants. While mineralization leads to the oxidation of carbon bonds in organic compounds, the degree of nitrogen oxidation remains largely unchanged and is (-3) N. As a next stage ammonium salts or ammonia are formed, i.e. the nitrogen compounds which undergo further oxidation-reduction reactions. These changes are dangerous to the environmentally and lead to the formation of nitrates (oxidation) and subsequently nitrogen oxides (reduction), which are the main environmental risk factors due to fertilization. The nitrogen circle was presented in Fig 2.

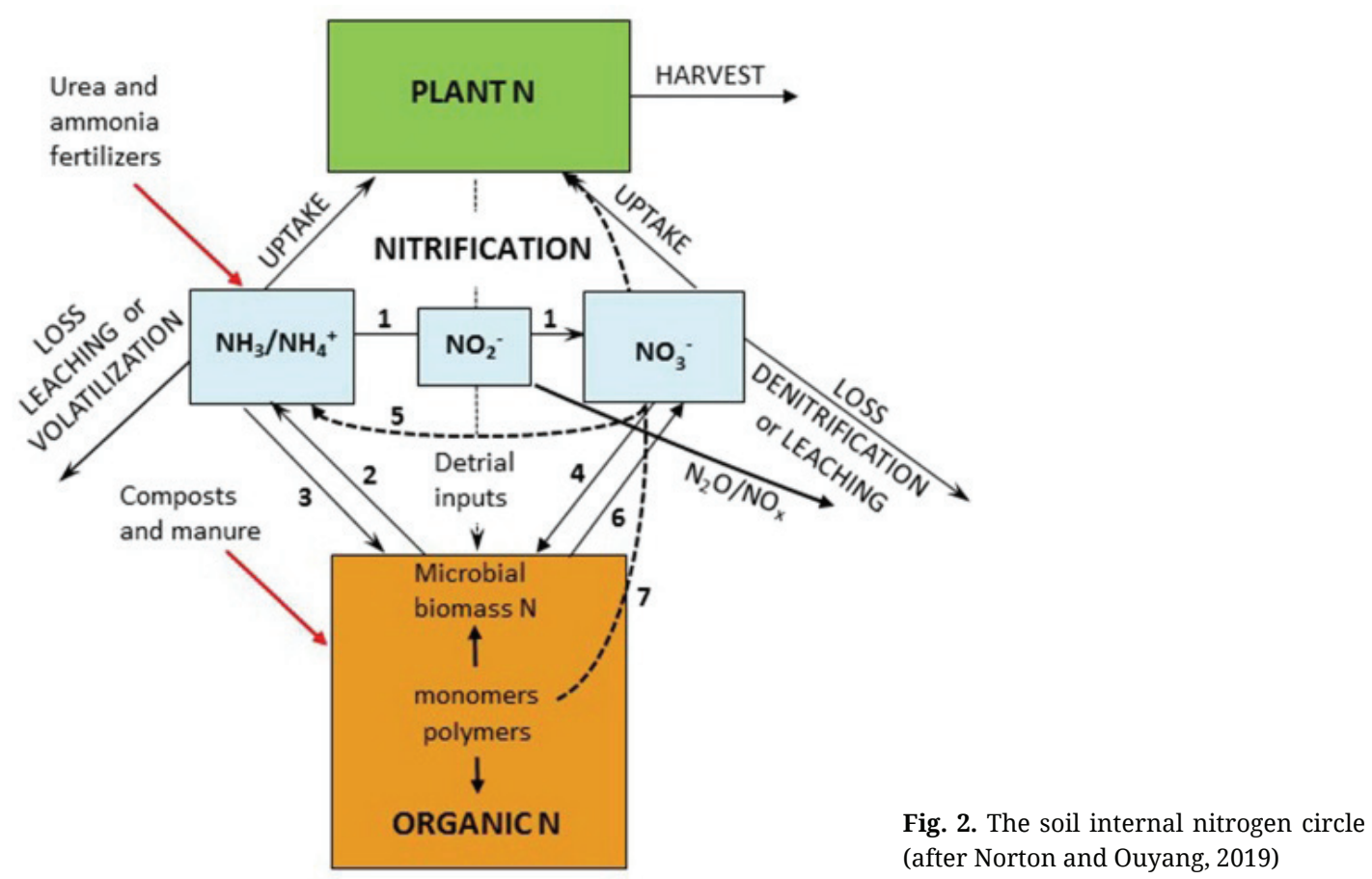


It should be emphasized, that while mineralization is a natural process necessary to maintain biological balance in the soil environment, providing plants with the necessary nitrogen source, further oxidation and reduction processes of ammonium ion constitute the main permanent risk of nitrogen losses from the soil environment as well as of its dissipation in the hydrosphere or return to the atmosphere in the form of nitrogen oxides or $\mathrm{N}_{2}$. Weather factors, and mainly precipitation and its distribution during the vegetation season, contribute to nitrate leaching, posing an environmental risk associated with organic fertilization, of particular importance under conditions of light soils. Nitrates leaching may result in contamination of drinking water with nitrates, which may pose a significant risk for human health (Królak and Raczuk, 2018). For this reason, the relevant legislation in the European Union sets the allowable deadlines for the use of organic fertilizers, and determines the allowable dose of nitrogen that can be introduced on one occasion, in the form of organic fertilizers, onto the surface unit of farmland (Sosulski et al., 2017).

Organic fertilization contributes to an increase in $\mathrm{N}_{2} \mathrm{O}$ emission from the soil. This emission from the soil fertilized with manure for many years was greater than that from the soil fertilized with mineral fertilizers (Jäger et al., 2011; Salehi et al., 2017). This is due to the increase in the content of simple organic compounds that provide electron donors and energy substrate for denitrifying bacteria in the soil environment (Rivett et al., 2007). In addition, the increase in the soil organic matter content due to organic fertilization enhances the activity of denitrifying bacteria by increasing the consumption of $\mathrm{O}_{2}$ in the mineralization process (Cannavo et al., 2004). Due to a relatively low content of organic carbon in the Polish soils, the conditions are generally unfavorable to denitrification, thus, periodic soil moisture rises, associated with precipitation incidents, constitute a key factor which supports denitrification and increases $\mathrm{N}_{2} \mathrm{O}$ emission (De Brogniez et al., 2015; Jager et al., 2011; Meng et al., 2005, Sosulski et al. 2017). In the literature, the opinion is widely adopted, that denitrification under conditions of organic fertilization is an important natural mechanism contributing effectively to the purification of nitrate loaded waters (Andersen et al., 2016; Fotyma and Fotyma, 2000; Greenan et al., 2006; Sosulski et al., 2017).

Another important factor, which may have significant influence on the $\mathrm{N}$ cycling, is the concentration of $\mathrm{O}_{3}$ in the air.

It was demonstrated that elevated $\mathrm{O}_{3}$ in soil is an important factor affecting microbial community structure and activity and may change $\mathrm{N}$ availability, which may lead to the increase $\mathrm{N}$ loss from soil (Simpson et al., 2014, Wu et al., 2016).

\section{Effect of weather conditions on transformations of nitrogen from mineral fertilizers in soils}

Nitrogen is introduced into the soil environment with nitrogen fertilizers in three forms; ammonium ion $\left(\mathrm{NH}_{4}^{+}\right)$, nitrate $\left(\mathrm{NO}_{3}^{-}\right)$or amide $\left(-\mathrm{NH}_{2}\right)$. The first two forms are directly available to plants, while the amide form found in urea, to be assimilable, must be hydrolysed by the urease enzyme produced by soil microorganisms.

\subsection{Amide form of nitrogen}

Weather factors are decisive for the rate of urea hydrolysis. Low temperatures below $6^{\circ} \mathrm{C}$ in the spring, persisting for a long time, significantly delays its decomposition into ammonium form, which can persist in this conditions for up to two weeks. At the soil temperature of about $10^{\circ} \mathrm{C}$, its hydrolysis usually does not take longer than one week. The urea hydrolysis process is conducive to environmental neutralization in soil microspaces, which results in the urea-forming ammonium ion being much more susceptible to volatilization in the form of ammonia than other nitrogenous mineral fertilizers. As a result, the spring weather patterns, characterized by a high temperature and good humidity, can significantly increase nitrogen losses in the form of ammonia from the cultivated field (Długosz and PiorowskaDługosz, 2016).

In modern mineral fertilization systems, deep application of mineral fertilizers is increasingly used. Under such conditions, the ammonium ion and ammonia resulting from urea hydrolysis are much more easily sorbed by the soil colloidal system compared to the surface application, which significantly reduces nitrogen losses as well as the related environmental effects (Mitchell et al., 1998).

\subsection{Ammonium form of nitrogen}

Ammonium ion in the soil environment is subject to nitrification, which is a typical biological oxidation process, carried out by autotrophic bacteria: Nitrosomonas and Nitrobacter, thus gaining the energy needed to bind and reduce carbon dioxide. This process is characterized by a low unit energy efficiency resulting in the need to oxidize large amounts of ammonium nitrogen. Nitrification intensity is strongly controlled by weather conditions., especially temperature (Gnida et al., 2016).

During the vegetation period with high temperatures, ammonium ions are converted to nitrates within a few days, what results, in the nutrient-rich soils, in plants feeding mainly on nitrate ions, irrespective of the form of nitrogen used for plant fertilization. This process takes place in two clearly discrete stages. In the first stage, ammonium ion is oxidized to nitrates (III), and to nitrates (V) in the second stage. Under normal weather conditions, nitrates (III) do not usually accumulate in soils. However, under conditions of excessive precipitation and the resulting limited oxygen supply to the soil, the atypically high levels of nitrates may accumulate under conditions of insufficient aeration. These circumstances may occur in waterlogged soils or under conditions of long-term precipitation, especially in heavier soils. Unusual excessive accumulation of nitrates (III) in the soil may lead to the formation of nitrosamines, the compounds which are undesirable in the soil (Laegreid et al., 1999, Rees et al., 2013).

Potential conditions for nitrite accumulation in the soil appear as a result of the excess nitrate content (e.g. as a consequence of excessive fertilization) when, due to the unfavorable weather conditions (e.g heavy rain), that occur, even only periodically, are the conditions for nitrates reduction. Identification of the conditions where nitrosamines may form in wet soils and water is important, because of the risk they may pose to human 
and animal health (Gilli et al., 1984; Jensen, 1982).

\subsection{Nitrate form of nitrogen}

The nitrification process during the vegetation period increases the mobility of mineral nitrogen compounds through diffusion migration, and is considered as beneficial to plants, despite that it acidifies the soil environment. However, when this process occurs beyond the vegetation period, it is an important factor increasing the risk of nitrogen losses through leaching, especially under heavy precipitation conditions (Myrbeck and Stanberg, 2014; Sosulski and Mercik, 2011). The level of nitrates in tile drainage is also affected by mineralization-immobilization processes in the soil, which are tied to temperature and elevated carbon dioxide (Wang et al., 2015).

It is common knowledge, that nitrates move more easily with water infiltrating the soil profile than ammonium cation (Sapek et al., 2002). The amounts of eluates of both nitrates and ammonium are similar only in soils not fertilized with nitrogen. Nitrate leaching is associated with the vertical movement of water deep into the soil profile, triggered by atmospheric precipitation and is higher than that of ammonium cations. The results of studies showed that a significantly lower nitrate leaching is observed in dry years than in wet years (Mitchell et al., 1998; Szucs, 1991).

Although the nitrate leaching research takes a considerable space in the domestic and foreign literature, it is difficult to unequivocally estimate the amount of nitrogen dispersed by leaching. It is estimated, that in view of the changing climatic and soil conditions in Poland, the average amount of nitrogen lost through leaching ranges from a few to about $40 \mathrm{~kg} \mathrm{~N}$ per hectare per year (Mitchell et al., 1998; Sosulski et al., 2017; Sosulski et al., 2011). In extremely adverse weather conditions (high rainfall), the loss can reach much higher values, of up to even $60-120 \mathrm{~kg}$ $\mathrm{N} \mathrm{ha}^{-1}$. In the model studies using red clay soils and ${ }^{15} \mathrm{~N}$ isotopic techniques, it was demonstrated that, under heavy rainfalls, high nitrogen losses may occur with surface runoff, especially during the initial plant growth period, amounting even up to $18 \%$ of the nitrogen dose applied (Zheng et al., 2016). That is why, efforts are being made to reduce the intensity of this process, and to reduce the amount of nitrates in the soil environment, in view of the hazards for the ground- and surface waters. The efforts include, inter alia, the introduction of new nitrogen fertilizers containing nitrification inhibitors as well as biodegradable coating fertilizers to ensure the gradual release of nitrogen, adapted to the rate of plant uptake. Technologies for in-depth fertilization have also been developed, based on the new generation fertilizers that provide plant nutrition exclusively with ammonium nitrate (Oertel et al., 2016; Rosas et al., 2015; Spicher et al., 2016).

When referring to the accuracy of the assessment of weather condition effects on nitrogen losses through leaching, it should be emphasized that one of the main reasons hampering this accuracy is the high intensity of nitrate transformations in the natural environment, which occur not only directly within the soil profile, but also, indirectly, outside the profile. The main type of these transformations is the reduction of nitrates to nitrogen oxides and to molecular nitrogen that occurs in the so- called transition zone or ecoton. This is the natural environment, in which the nitrate flux moves between the agricultural space and the ground- and surface waters. It consists of, among others, unsaturated and saturated zones of soils, underground and surface drainage systems, mid-field water reservoirs, marshes, peatlands, woodlands, etc. Various studies emphasize the importance of the transition zone in self-cleaning of waters, moving from agricultural areas to the widely understood hydrosphere (Cors and Tychon, 2001; Dhondt et al., 2001). Denitrification is a decisive process for removal of excess nitrates from infiltrating waters (Sosulski et al., 2016).

\subsection{Nitrogen in the form of $\mathrm{N}_{2} \mathrm{O}$}

As was shown in many studies, nitrates dominate in the soil solutions sampled from soils remaining in good agriculture and having a well-regulated reaction $(\mathrm{pH})$. Under anaerobic conditions, which periodically occur in topsoil after heavy precipitation incidents, nitrates are reduced to gaseous products such as nitrous oxide $\left(\mathrm{N}_{2} \mathrm{O}\right)$, nitric oxide-2 (NO) and molecular nitrogen $\left(\mathrm{N}_{2}\right)$. Nitrate or nitrite reductase containing bacteria are mainly capable of carrying out this process. The intensity of this process, in addition to precipitation, is favored by the high organic matter content as well as neutral soil reaction ( $\mathrm{pH}$ about 7). Denitrification occurs in all soils, and is a natural process that provides links between the soil nitrogen cycle and the global nitrogen store, which is the atmosphere (Signor and Cerri, 2013).

The analysis of soil conditions for the oxidation-reduction processes indicates that nitrification and denitrification are a sequence of closely interrelated transformations showing a layer-specific differentiation. Nitrification is predominant in the upper soil layer, although in the so-called micro-zones denitrification takes place, whereas in deeper layers, where nitrates migrate, denitrification dominates. The intensity of these processes is controlled by weather conditions that shape the temperature and aeration of the soil profile. The analysis of the zonationmodel that describes the oxidation-reduction transformations in the soil profile, results in the conclusion that denitrification is a natural mechanism limiting nitrate leaching into groundwater (Jahangir et al., 2012). Based on a linear regression the model was created to describe the analyzed variables. As a result of Pearson's test and Shapiro-Wilk the variables which did not fulfill the tests assumptions were eliminated. In the resulting linear regression model, $63 \%$ of the variability of $\mathrm{N}_{2} \mathrm{O}$ emissions is explained by variability in use of nitrogen fertilizers. The nitrogen losses by leaching in this mechanism are replaced by nitrogen gas losses through volatilization in the form of nitrogen oxides and molecular nitrogen. From the environmental point of view, denitrification should be assessed as a positive process limiting the mineral nitrogen leaching from farmland, especially under conditions of increased atmospheric precipitation (KolasaWięcek, 2013; Sosulski et al., 2013).

Recent interest in the drivers of denitrification and nitrification processes in cultivated soils is due to the fact, that they release significant amounts of nitrous oxide, which is a major GHG, with direct global warming potential 298 times higher than that of carbon dioxide (Rosas et al., 2015). According to the 
National Centre for Emission Balancing and Management, more than $85 \%$ of $\mathrm{N}_{2} \mathrm{O}$ emissions in Poland originate in agriculture, including around 70\% from cultivated soils (KOBiZE, 2014). One of the main factors affecting the intensity of $\mathrm{N}_{2} \mathrm{O}$ formation, apart from the content of $\mathrm{N}^{-\mathrm{NO}_{3}}$ in the soil and soil $\mathrm{pH}$, is the soil temperature. Weather changes that increase the air temperature will thus significantly increase the emission of this gas from the soil. This process is further shaped by a whole series of other factors, such as soil moisture, its granulometric composition, fertilization level, which makes it difficult to determine the specific role of particular factors in the emission of nitrous oxide (Amha and Bohne, 2011; Firestone and Davidson, 1989).

A detailed analysis of the interdependence of factors controlling $\mathrm{N}_{2} \mathrm{O}$ emission indicates that the intensity of this process is determined by the interrelated weather conditions, which control the soil moisture- and nitrate contents (Dobbie et al., 2003; Vitale et al., 2017). Referring to the conditions prevailing in Poland, Goliński et al. (2000) demonstrated that the overall conditions of the Polish soils do not, generally, favor denitrification processes, in view of the dominance of light soils with low water content, easily overdrying in the absence of precipitation. Weather conditions that cause soil moisture to persist in the range of $60-90 \%$ of the capillary capacity, for a longer time period, encourage a higher intensity of the denitrification processes and associated $\mathrm{N}_{2} \mathrm{O}$ emissions (Smith et al., 1998). It is believed that in the excessively waterlogged soils, the major driver behind $\mathrm{N}_{2} \mathrm{O}$ emission is denitrification, while in the optimally wet soils (35-60\% of the capillary capacity) the process is mainly governed by nitrification (Bateman and Baggs, 2005). Moreover, it was shown that the maximum $\mathrm{N}_{2} \mathrm{O}$ emission from the soil is most likely to be observed immediately after heavy rain moistening the overdried soil (Flessa et al., 1995). Such phenomena have been observed in recent weather anomalies, characterized by prolonged drought episodes terminated by the long-lasting heavy precipitation periods (Westra et al., 2013). $\mathrm{N}_{2} \mathrm{O}$ emissions from the soil occur not only during vegetation period, but also during the winter. Kaiser and Ruser (2000) have shown that as much as $50 \%$ of the gas emissions occur in winter, which is due to the alternating processes of freezing and de-freezing of the soil (Mogge et al., 1999).

\section{Nitrogen in $\mathrm{NH}_{3}$ form}

An important issue in agriculture is the transformation of ammonium nitrogen leading to ammonia emission, which is one of the important elements of nitrogen dissipation from agricultural areas. Literature holds that the dominant source of ammonia emission in agriculture is animal production, accounting for $3 / 4$ of its emission. Approximately $25 \%$ of the total ammonia emission from agriculture is released due to the transformation of fertilizers. According to Sapek et al. (2002), the ammonia emission from agricultural areas in 2000 amounted to about 300 Mtand showed a downward trend. Emissions of ammonia from cultivated fields under conditions of exclusive mineral fertilization, without natural fertilizers, vary between $2-6 \mathrm{~kg} \mathrm{ha}^{-1}$ a year (Sosulski and Łabętowicz, 2007). The scale of this emission is largely related to the soil reaction $(\mathrm{pH})$ and the technique of fertilizer application. Soil liming and surface application of natural and mineral fertilizers favors this emission. The increasingly implemented techniques of in-depth application of slurry and mineral fertilizers greatly contribute to reducing this emission in agriculture (Misselbrook et al., 2019). A good example is the dynamic development of the RSM liquid fertilizer (ammonium nitrate + urea) technology in Poland. RSM is a coarce spraying technique or a filling technique. Using one of the techniques depends on the stage of development of the plant (Sztuder, 2007).

The weather conditions during the vegetation period significantly affect the processes of ammonia formation and its emission from the soil, via the influence on the activity of soil microorganisms, soil moisture and aeration. Under conditions of good soil moisture, ammonia resulting from the transformations of the organic and mineral fertilizers, is dissolved in soil solutions, in which as ammonium ion $\left(\mathrm{NH}_{3}+\mathrm{H}_{2} \mathrm{O}=\mathrm{NH}_{4} \mathrm{OH}\right)$ is predominantly subject to processes of exchangeable sorption.

When there is no precipitation, especially after applying fertilizers, the major part of ammonia is volatilized in view of good soil aeration. The amount of ammonia emission from the area of agricultural production cannot be equated with the amount of nitrogen dispersed in this way from agriculture to the natural environment, because significant amounts of ammonia are returned to the soil with precipitation water. It is estimated, that the amount of atmospheric ammonia returning to the soil is approximately $3.9 \mathrm{~N}-\mathrm{NH} \mathrm{kg} \mathrm{ha-1}$ per year( Sapek et al., 2002). Taking into account the area of agricultural land, it can be calculated, that the amount of nitrogen deposited solely by wet precipitation, in the scale of Poland, equals the amount of nitrogen that is released from the soil as a result of fertilization (Sosulski and Łabętowicz, 2007).

\section{Conclusions}

From the analysis of the effects of weather conditions on fertilizer changes, it can be inferred, that changes in soil temperature and moisture during vegetation period constitute major drivers controlling the mineralization of organic nitrogen fertilizer and the oxido-reductive transformations of mineral nitrogen. This is determined by the weather unpredictable dynamics and variability, increasing over the recent years. This may lead locally to a periodic disruption of the dynamic balance of fertilizer nitrogen transformations in the soil environment. Such a disruption of transformations processes causes their unfavorable orientation resulting in excessive nitrate leaching and excessive emission of ammonia and nitrous oxide. This requires that appropriate preventive measures will be taken on the part of science and agricultural practice, aiming at the development of new generations of fertilizers and the introduction of novel cultivation technologies, in particular, the in-depth application of fertilizers.

The above analysis indicates, that transformations of nitrogen compounds in the soil, caused predominantly by the climate system, result in nitrogen dispersion from the agricultural production area. The dispersion in the form of molecular nitrogen 
is mainly the result of denitrification processes. By this way over $50 \%$ of nitrogen lost from agriculture is dissipated from the agricultural land. From the agricultural point of view, denitrification is a process that limits the resources of available nitrogen, but from the environmental viewpoint, this process should be considered as a natural mechanism of environmental self-purification and water protection. Dilution of nitrogen from agricultural areas by leaching, although constituting only about $25 \%$ of the total loss of this element, is considered to be the most cumbersome for the environment.

\section{Acknowledgments}

This paper was prepared as part of the Project "Support for low-emission agriculture capable of adaptation to climate change currently and in the perspectives of 2030 and 2050" (acronym LCAgri). The Project has received funding by NCBiR from the BIOSTRATEG Programme.

\section{References}

Amha, Y., Bohne, H., 2011. Denitrification from the horticultural peats: effects of $\mathrm{pH}$, nitrogen, carbon and moisture contents. Biology and Fertility of Soils 47, 293-302. https://doi.org/10.1007/s00374-010-0536-y

Arbacaukas, J., Maseviciene, A., Žickiene, L., Staugaitis, G., 2018. Mineral nitrogen in soils of Lithuania's agricultural land: comparison of oven-dried and field-moist samples. Zemdirbyste-Agriculture 105(2), 99-104. https://doi.org/10.13080/z-a.2018.105.013

Bateman, E.J., Baggs, E.M., 2005. Contibution of nitrification and denitrification to $\mathrm{N}_{2} \mathrm{O}$ emission from soils at different water - filled pore space. Biology and Fertility of Soils 41, 379-388. https://doi. org/10.1007/s00374-005-0858-3

Bednarek, A., Szklarek, S., Zalewski, M., 2014. Nitrogen pollution removal from areas of intensive farming-comparison of various denitrification biotechnologies. Ecohydrology and Hydrobiology 14(2). https:// doi.org/10.1016/j.ecohyd.2014.01.005

Bouwman, A.F., Beusen, A.H.W., Griffioen, J., Van Groenigen, J.W., Hefting, M.M., Oenema, O., Van Puijenbroek, P.J.T.M., Seitzinger, S., Slomp, C.P., Stehfest, E., 2013. Global trends and uncertainties in terrestrial denitrification and $\mathrm{N}_{2} \mathrm{O}$ emissions. Philosophical Transactions of the Royal Society B 368, 20130112. https://doi.org/10.1098/ rstb.2013.0112

Cannavo, P., Richaume, A., Lafolie, F., 2004. Fate of nitrogen and carbon in the vadose zone: in situ and laboratory measurements of seasonal variations in aerobic respiratory and denitryfying activities. Soil Biology and Biochemistry 36, 463-478. https://doi.org/10.1016/ j.soilbio.2003.10.023

Cors, M., Tychon, B., 2001. Controls on denitrification in riparian buffer strip in small headwater catchment in South Belgium. 11 th Nitrogen Workshop 9-12 September Reims France 61-62. http://yadda. icm.edu.pl/yadda/element/bwmeta1.element.agro-article-79e2dc8f0969-4755-8770-70286c2fc40b?q=bwmeta1.element.agro-volumef43db9c4-a0ac-47dd-beea-554f76bb7ea9;47\&qt=CHILDREN-STATELESS

De Brogniez, D., Ballabio, C., Stevens, A., Jones, R.J.A., Montanarella, L., van Wesemae, B., 2015. A map of topsoil organic carbon content of Europe generated by a generalized additive model. European Journal of Soil Science 66, 121-134. https://doi.org/10.1111/ejss.12193

Dhondt, K., Boeck, P., Van Cleemput, O., Hofman, G., De Troch, F., 2001. Nitrate removal and denitrification related ${ }^{15} \mathrm{~N}$ isotopic fractionation in riparian buffer strip. 11 th Nitrogen Workshop 9-12 September Reims France 67-70.
Dirnbőck, T., Foldal, C., Djukic, I., Kobler, J., Haas, E., Kiese, R., Kitzler, B., 2017. Historic nitrogen deposition determines future climate change effects on nitrogen retention in temperate forests. Climatic Change 144, 221-235. https://doi.org/10.1007/s10584-017-2024-y

Długosz, J., Piotrowska-Długosz, A., 2016. Spatial variability of soil nitrogen forms and the activity of N-cycle enzymes. Plant Soil and Environment 62, 502-507. https://doi.org/10.17221/251/2016-PSE

Dobbie, K.E., Smith, K.A., 2003. Nitrous oxide emission factors for agricultural soils in Great Britain: The impact of soil water-filled pore space and other controlling variables. Global Change Biology 9, 204-218. https://doi.org/10.1046/j.1365-2486.2003.00563.x

Erbas, B.C, Solakoglu, E.G., 2017. In the Presence of Climate Change, the Use of Fertilizers and the Effect of Income on Agricultural Emissions, Sustainability 9, 1989. https://doi.org/10.3390/su9111989

Firestone, M.K., Davidson, E.A., 1989. Microbiological basis of NO and $\mathrm{N}_{2} \mathrm{O}$ production and consumption in soils. In M.O. Andreae and D.S. Schimel (Eds) Exchange of Trace Gases Between Terrsestial Fcosystems and the Atmosphere, 7-12. New York, John Wiley and Sons.

Flessa, H., Dorsch, P., Beese, F., 1995. Seasonal variation of $\mathrm{N}_{2} \mathrm{O}$ and $\mathrm{CH}_{4}$ fluxes in differently managed arable soils in southern Germany. Journal of Geophysical Research 100, D11: 23, 15-23, 124. https://doi. org/10.1029/95JD02270

Fotyma, E., Fotyma, M., 2000. Zawartość azotu mineralnego w glebie jako wskaźnik potrzeb nawozowych roślin i stanu środowiska glebowego. Nawozy i Nawożenie 4(5), 91-101

Gilli, G., Corrao, G., Favilli, S., 1984. Concentration of nitrates in drinking water and incidence of gastric carcinomas: first destriptive study of the Piemonte region (Environmental nitrosoamine pollution). Science of the Total Environment 34, 35-48. https://doi.org/10.1016/00489697(84)90039-1

Gnida, A., Wiszniowski, J., Felis, E., Sikora, J., Surmacz-Górska, J., Miksch, K., 2016. The effect of temperature on the efficiency of industrial wastewater nitrification and its (geno)toxicity. Archives of Environmental Protection 42(1), 27-34. https://doi.org/10.1515/aep2016-0003

Goliński, J., Stępniewska, Z., Stępniewski, W., Ostrowski, J., Szmagara, A., 2000. A contribution to the assessment of potential denitrification in arable mineral soil of Poland. Journal Water and Land Development 4, 175-183. http://yadda.icm.edu.pl/yadda/element/bwmeta1. element.agro-article-2812281a-ce02-453b-8655-3d544fd778ec

Greenan, C.M, Moorman, T.B., Kaspar, T.C., Parkin, T.B., Jaynes, D.B., 2006. Comparing carbon substrates for denitrification of subsurface drainage water. Journal of Envinronmental Quality 35(3), 824-829. https:// doi.org/10.2134/jeq2005.0247

Haohao, W., Xingkai, X., Cuntao, D., TuanSheng, L., Weiguo, C., 2017. Effect of carbon and nitrogen addition on nitrous oxide and carbon dioxide fluxes from thawing forest soils, International Agrophysics 31, 339-349. https://doi.org/10.1515/intag-2016-0065

Iglesias, A., Garrote L., 2015. Adaptation strategies for agricultural water management under climate change in Europe. Agricultural Water Management 155, 113-124. https://doi.org/10.1016/ j.agwat.2015.03.014

Inglett, P.W, Reddy, K.R., and Corstanje, R., 2005. Anaerobic Soils. In Encyclopedia of Soils in the Environment. D. Hillel (ed). Academic Press, 71-78.

Intergovernmental Panel Climate Change (IPCC), 2007. Climate Change 2007: The Physical Science Basis: Contribution of Working Group I to the Fourth Assessment Report of the Intergovernmental Panel on Climate Change. Cambridge University Press, Cambridge, U.K. and New York, NY. https://www.ipcc.ch/report/ar4/wg1/

Jahangir, M.M.R., Khalil, M.I., Johnston, P., Cardenas, L.M., Hatch, D.J., Butler, M., Barrett, M., O’flaherty, V., Richards, K.G., 2012. Denitrification potential in subsoils: A mechanism to reduce nitrate leaching to groundwater. Agriculture, Ecosystems and Environment 147, 13-23. https://doi.org/10.1016/j.agee.2011.04.015 
Jäger, N., Stange, C.F., Ludwig, B., Flessa, H., 2011. Emission rates of N2O and $\mathrm{CO} 2$ from soils with different organic matter content from tree long-term fertilization experiments - a laboratory study. Biology and Fertility of Soils 47, 483-494. https://doi.org/10.1007/s00374-0110553-5

Jensen, O.M., 1982. Nitrate in drinking water and cancer in northern Jutland with special reference to stomach cancer (Nitrosoamines) Ecotoxicology and Environmental Safety V-6, 258-267 https://doi. org/10.1016/0147-6513(82)90016-1

Kaiser, E.A., Ruser, R., 2000. Nitrous oxide emission from arable soils in Germany - An evaluation of six long-term experiments. Journal of Plant Nutrition and Soils Science 163, 249-260. https://doi. org/10.1002/1522-2624(200006)163:3<249::AID-JPLN249>3.0.CO;2-Z

KOBiZE, 2014. National inventory report. Inventory of greenhouse gases in Poland for 1988-2012. Report prepared for the purposes of the United Nations Framework Convention on Climate Change from Kyoto. The National Center for Balancing and Emission Management (KOBiZE). Warszawa, 373

Kolasa-Więcek, A., 2013. Modeling Nitrous oxide emissions from agricultural sources with the use of linear regression. Journal of Research Applications in Agricultural Engineering 58(1).

Królak, E., Raczuk, J., 2018. Nitrate concentration-related safety of drinking water from various sources intended for consumption by neonates and infants. Archives of Environmental Protection 44 (1), 3-9. https://doi/org/10.24425/118176

Laegreid, M., Bockman, O.C., Kaarstad, O., 1999. Agriculture, Fertilizers and Environment. CABI Publishing in association with Norsk Hydro ASA.

Luce, M.S., Whalen, J.K., Ziadi, N., Zebarth, B.J., 2011. Nitrogen dynamics and indices to predict soil nitrogen supply in humid temperate soils. Advances in Agronomy 112, 55-102. https://doi.org/10.1016/B978-012-385538-1.00002-0

Mariano, E., Jones, D.L., Hill, P.W., Trivelin, P.C.O., 2016. Mineral nitrogen forms alter ${ }^{14} \mathrm{C}$-glucose mineralisation and nitrogen transformations in litter and soil from two sugarcane fields. Applied Soil Ecology 107, 154-161. https://doi.org/10.1016/j.apsoil.2016.05.019

Meng, L., Ding, W., Cai, Z., 2005. Long-term application of organic manure and nitrogen fertilizer on $\mathrm{N}_{2} \mathrm{O}$ emissions, soil quality and crop production in a sandy loam soil. Soil Biology and Biochemistry 37(11), 2037-2045. https://doi.org/10.1016/j.soilbio.2005.03.007

Misselbrook, T., Bittman, S., Cordovil, C.M.d.S., Rees, B., Sylvester-Bradley, R., Olesen, J., Vallejo, A., 2019. Field application of organic and inorganic fertilizers and manure. Draft section for a Guidance Document, Task Force on Reactive Nitrogen under the UNECE Air Convention, with support from the European Commission, Brussels 30.091.10 .2019 , p. 16

Mitchell, J.K., Walher, S.E., Hirschi, M.C., Cooke, R.A.C., Banasik, K., 1998. Nitrate losses under various nitrogen management system. Zeszyty Problemowe Postępów Nauk Rolniczych 458, 431-442.

Mogge, B., Kaiser, E.A., Munch, J.C., 1999. Nitrous oxide and denitrification N-losses from agricultural soils in the Bornhoved Lake region: influence of organic fertilizers and land-use. Soil Biology and Biochemistry 31, 1245-1252. https://doi.org/10.1016/S0038-0717(99)00039-5

Myrbeck, A., Stenberg, M., 2014. Changes in Nleaching and crop production as a result of measures to reduce $\mathrm{N}$ losses to water in a 6-yr crop. Soil Use and Management 30, 219-230. https://doi.org/10.1111/ sum. 12118

Nivelle, E., Verzeaux, J., Habbib, H., Kuzyakov, Y., Decocq, G., Roger, D., Lacoux, J., Duclercq, J., Spicher, F., Nava-Saucedo, J.E., Catterou, M., Dubois, F., Tetu, T., 2016. Functional response of soil microbial communities to tillage, cover crops and nitrogen fertilization. Applied Soil Ecology 108, 147-155. https://doi.org/10.1016/j.apsoil.2016.08.004

Norton, J. Ouyang, Y., 2019. Controls and Adaptive Management of Nitrification in Agricultural Soils. Frontiers in Microbiology. https://doi. org/10.3389/fmicb.2019.01931
Oertel, C., Matschullat, J., Zurba, K., Zimmermann, F., Erasmi, S., 2016. Greenhouse gas emissions from soils-A review. Chemie der Erde-Geochemistry 76(3), 327-352. https://doi.org/10.1016/j.chemer.2016.04.002

Olesen, J.E., Trnka, M., Kersebaum, K.C., Skjelvíg, A.O., Seguin, B., Peltonen-Sainio, P., Rossi, F., Kozyra, J., Micale, F., 2011. Impacts and adaptation of European crop production systems to climate change, European Journal of Agronomy 34, 96-112. https://doi.org/10.1016/ j.eja.2010.11.003

Oni, S.K., Mieres, F., Futter, M.N., Laudon, H., 2017. Soil temperature responses to climate change along a gradient of upland-riparian transect in boreal forest. Climatic Change 143, 27-41. https://doi. org/10.1007/s10584-017-1977-1

Rees, R.M. et al., 2013. Nitrous oxide emissions from European agriculture - an analysis of variability and drivers of emissions from field experiments. Biogeosciences 10, 2671-2682. https://doi.org/10.5194/ bgd-9-9259-2012

Rivett, M.O., Smith, J.W.N., Buss, S.R., Morgan, P., 2007. Nitrate occurrence and attenuation in the major aquifers of England and Wales. Quarterly Journal of Engineering and Hydrogeology 40(4), 335-352. https://doi.org/10.1144/1470-9236/07-032

Rosas, F., Babcock, B.A., Hayes, D.J., 2015. Nitrous oxide emission reductions from cutting excessive nitrogen fertilizer application, Climatic Change 132, 353-367. https://doi.org/10.1007/s10584-015-1426-y

Rutting, H., Aronsson, H., Delin, S., 2018. Efficient use of nitrogen in agriculture, Nutr Cycl Agroecosyst 110, 1-5. https://doi.org/10.1007/ s10705-017-9900-8

Salehi, A., Fallah, S., Sourki, A.A., 2017. Organic and inorganic fertilizer effect on soil $\mathrm{CO}_{2}$ flux, microbial biomass and growth of Nigella sativa L., International Agrophysics 31, 103-116. https://doi.org/10.1515/ intag-2016-0032

Sapek, A., Sapek, B., Pietrzak, S., 2002. Obieg i bilans azotu w rolnictwie polskim. Nawozy i Nawożenie 1, 100-121.

Signor, D., Cerri, C.E.P., 2013. Nitrous oxide emissions in agricultural soils: a review, Pesq. Agropec. Trop., Goiânia 43(3), 322-338, jul./set. 2013

Simpson, D., Arneth, A., Mills, G., Solberg, S., Uddling, J., 2014. Ozone - the persistent menace: interactions with the $\mathrm{N}$ cycle and climate change, Current Opinion in Environmental Sustainability 9-10, 9-19. https://doi.org/10.1016/j.cosust.2014.07.008

Smith, K.A., Thomson, P.E., Clayton, H., Mc Taggart, I.P., Conen, F., 1998. Effects of Temperature, water content and nitrogen fertilization on emisssion of nitrous oxide by soil. Atmospheric Environment 32, 3301-3309. https://doi.org/10.1016/S1352-2310(97)00492-5

Sosulski, T., Łabętowicz, J., 2007. Oszacowanie rozpraszania azotu z rolnictwa polskiego do atmosfery oraz wód powierzchniowych i gruntowych. Postępy Nauk Rolniczych 5, 3-19.

Sosulski, T., Mercik, S., 2011. The dynamics of mineral nitrogen movement in the soil profile in long-term experiments. Ecological Chemistry and Engineering. A 18(4), 611-617.

Sosulski, T., Stępień, W., Mercik, S., Szara, E., 2011. Crop fields and nitrogen balance in long-term fertilization experiments. Nawozy i Nawożenie 42, 41-50.

Sosulski, T., Szara, E., Stępień, W., 2013. Dissolved organic carbon in Luvisol under different ferilization and crop rotation. Soil Science Annual 64(3), 114-119. https://doi.org/10.2478/ssa-2013-0015

Sosulski, T., Szara, E., Stępień, W., Szymańska, M., Borowska-Komenda, M. 2016. Carbon and nitrogen leaching in long-term experiment and $\mathrm{DOC} / \mathrm{N}-\mathrm{NO}_{3}$ ratio in drainage water as an indicator of denitrification potential in different fertilization and crop rotation systems. Frasenius Environmental Bulletin 25 (8), 2813-2824.

Sosulski, T., Szara, E., Szymańska, M., Stępień, W., 2017. № emission and $\mathrm{N}$ and $\mathrm{C}$ leaching from the soil in relation to long-term and current mineral and organic fertilization. Plant Soil and Environment 63(3), 97-104. https://doi.org/10.17221/205/2016-PSE

Stanford, G., Frere, M.H., Schwaninger, D.H., 1973. Temperature coefficient of soil nitrogen mineralization. Soil Science 115, 321-323. 
Stanford, G., Steine, E.P., 1974. Nitrogen mineralization water relations in soils. Soil Science Society of America, Proceedings 38. https://doi. org/10.2136/sssaj1974.03615995003800010032x

Stein, L.Y., Klotz, M.G., 2016. The nitrogen Cycle. Current Biology 26(3), R94-R98 https://doi.org/10.1016/j.cub.2015.12.021

Stevenson, F.J., 1982. Organic forms of soil nitrogen. In Nitrogen in agricultural soils. Agronomy Monographs 22. Madison. https://doi. org/10.2134/agronmonogr22.c3

Sztuder, H., 2007. Production and ecological evaluation at different methods of fertilizers application in winter wheat cultivation. Agricultural Engineering 3(91), 167-172

Szucs, M., 1991. Nitrate movement in the soil. Roczniki Gleboznawcze - Soil Science Annual T XLII 3/4, 121-128.

Villar, N., Aranguren, M., Castellon, A., Besga, G., Aizpurua, A., 2019. Soil nitrogen dynamics during an oilseed rape (Brassica napus L.) growing cycle in a humid Mediterranean climate, Scientific Reports 9, 13864

Vitale, L., Polimeno, F., Ottaiano, L., Maglione, G., Tedeschi, A., Mori, M., De Marco, A., Di Tommasi, P., Magliulo, V., 2017. Fertilizer type influences tomato yield and soil $\mathrm{N}_{2} \mathrm{O}$ emission. Plant Soil and Environment 63, 105-110. https://doi.org/10.17221/678/2016-PSE

Wang, S., Wen, X., Luo, Y., Tang, G., Zhao, Z., Huang, J., 2010. Does the Global Warming Pause in the Last Decade: 1999-2008? Advances in Climate Change Research 1, 49-54. https://doi.org/10.3724/ SP.J.1248.2010.00049
Wang, Z., Qi, Z., Xue, L., Bukovsky, M., Helmers, M.J., 2015. Modeling the impacts of climate change on nitrogen losses and crop yield in a subsurface drained fields. Climatic Change 129, 323-335. https://doi. org/10.1007/s10584-015-1342-1

Westra, S., Alexander, L.V., Zwiers, F.W., 2013. Global increasing trends in annual maximum daily precipitation. Journal of Climate 26, 3904-3918. https://doi.org/10.1175/JCLI-D-12-00502.1

Wiśniewski, P., 2019. Assessment of nitrous oxide emissions from agricultural soils at a local level in Poland. International Agrophysics 33, 303-311 https://doi.org/10.31545/intagr/105530

Wu, H., Li, Q., Lu, C., Zhang, L., Zhu, J., Dijkstra, F.A., Yu, Q., 2016. Elevated ozone effects on soil nitrogen cycling differ among wheat cultivars. Applied Soil Ecology 108, 187-194. https://doi.org/10.1016/ j.apsoil.2016.08.015

Zhang, S., Zheng, Q., Noll, L., Hu, Y., Wanek, W., 2019. Environmental effects on soil microbial nitrogen use efficiency are controlled by allocation of organic nitrogen to microbial growth and regulate gross N mineralization, Soli Biology and Biochemistry 135, 304-315. https://doi.org/10.1016/j.soilbio.2019.05.019

Zheng, H.J., Zuo, J.C., Wang, L.Y., Li, Y.J., Liao, K.T., 2016. ${ }^{15} \mathrm{~N}$ isotope tracing of nitrogen runoff on red soil sloping uplands under simulated rainfall conditions. Plant Soil and Environment 62, 416-421. https:// doi.org/10.17221/246/2016-PSE

\section{Przemiany nawozów azotowych w warunkach klimatu umiarkowanego}

\author{
Słowa kluczowe \\ Zmiany klimatu \\ Azot \\ Nawozy \\ Rolnictwo \\ Gleba \\ Podtlenek azotu
}

\begin{abstract}
Streszczenie
Rolnictwo przyczynia się do globalnego ocieplenia głównie poprzez emisję metanu i podtlenku azotu. Szczególnie istotny jest udział podtlenku azotu, który stanowi aż 50\% całkowitej emisji z gruntów rolnych. Jest on wytwarzany w wyniku przemiany mikrobiologicznej azotu wprowadzanego do gleby wraz z nawozami mineralnymi. Zmiany warunków pogodowych w odpowiedzi na zmiany klimatu mogą istotnie wpłynąć na efektywność wykorzystania azotu nawozowego w rolnictwie, a w konsekwencji pociągnąć za sobą niepożądane skutki środowiskowe. Kwestia ta ma szczególne znaczenie ze względu na dominującą rolę, jaką ten element nawozowy odgrywa w rolnictwie, a z drugiej strony ze względu na globalne ryzyko środowiskowe w ramach tzw. cyklu azotowego. Przeprowadzona w pracy analiza wskazuje, że spowodowane głównie warunkami klimatycznymi przemiany związków azotu w glebie powodują uwalnianie się azotu z obszaru produkcji rolnej. Dyspersja w postaci azotu molekularnego jest głównie wynikiem procesów denitryfikacji. W ten sposób ponad 50\% azotu traconego z rolnictwa jest usuwane z gruntów rolnych. Z rolniczego punktu widzenia denitryfikacja jest procesem, który ogranicza zasoby dostępnego azotu, ale z punktu widzenia ochrony środowiska proces ten należy uznać za naturalny mechanizm samooczyszczania się środowiska i ochrony wód. Chociaż stanowi on jedynie około $25 \%$ całkowitej straty tego pierwiastka, to jednak rozcieńczanie azotu z obszarów rolniczych poprzez ługowanie jest uważane za najbardziej uciążliwe dla środowiska wodnego.
\end{abstract}

